\title{
Sero-prevalence of foot and mouth disease in cattle in Borena Zone, Oromia regional state, Ethiopia
}

\author{
Asamenew Tesfaye ${ }^{1^{*}}$, Mesfin Sehale ${ }^{1}$, Ashebir Abebe ${ }^{1}$, Ayelech Muluneh ${ }^{1}$ and Daniel \\ Gizaw $^{1}$
}

${ }^{1}$ National Animal Health Diagnostic and Investigation Center (NAHDIC), P.O. Box 04, Sebeta, Ethiopia

*Corresponding author: National Animal Health Diagnostic and Investigation Center, P.O. Box 04, Sebeta, Ethiopia, Email:asefiker@yahoo.com

http://dx.doi.org/10.4314/evj.v20i1.4

\section{Abstract}

A cross-sectional study was carried out between April and November 2015 to investigate the sero-prevalence of foot-and-mouth disease (FMD) in cattle in Borena zone using 3ABC-Enzyme Linked Immuno Sorbent Assay (ELISA) to detect antibody against foot-and-mouth disease virus and semi structured questionnaire. A total of 363 sera samples were collected from nine peasant associations found in three different districts. An overall seroprevalence of 42.7\% (95\%: CI= 37.7-47.84) was found during the study. There was statistically significant difference among the districts $\left(\mathrm{x}^{2}=10.43, \mathrm{p}=0.005\right)$ and the highest prevalence was found in Dire district which accounted for 52.8\% (95\%: CI, 44.0-61.4). The highest sero-prevalence was recorded in Soda peasant association of Dire district and Surupa peasant association of Yabello district which accounted for 65.5\% (95\%: CI, 49.4-78.5) and 65.0\% (95\%: CI= 40.4-78.5), respectively. Statistical significant difference in footand-mouth disease seroprevalence $\left(\mathrm{x}^{2}=31.1, \mathrm{p}=0.000\right)$ was found among the peasant associations. Similarly, there was significance difference $\left(x^{2}=17.4, p=0.000\right)$ in the prevalence of foot-and-mouth disease between age groups. Though the seroprevalence foot-and-mouth disease was higher in females than in males, there was no significant difference $\left(x_{2}=1.63, \mathrm{p}=0.202\right)$ between sex. The different risk factors analyzed during this study indicated that, peasant associations (PAs), district and age were seen to be significantly associated $(p<0.05)$ with the seroprevalence of foot-and-mouth disease. The questionnaire survey revealed that foot-and-mouth disease outbreak was commonly seen during June to August (Short rainy season) and December to February (Long dry season), locally called Adolessa and Bona, respectively. Younger (1-3 years) animals were most susceptible than calf and adults (>3years). Moreover, an extrinsic factor like dry season enforces pastoralist to travel a longer distance to look for grazing lands and water sources that creates 
suitable conditions for foot-and-mouth disease transmission between infected and susceptible animals. Therefore, foot-and-mouth disease is an endemic and transboundary animal disease in Borena zone that calls for an effective control strategies to be in place.

Keywords: Borena, FMD, Questionnaire survey, Sero-prevalence, 3ABC-ELISA

\section{Introduction}

Livestock is the mainstay of the livelihood of the majority of Ethiopians, providing draught power for crop production, source of meat and milk, and cash income for farmers (Bekele Megersa et al., 2009). Cattle are the most important ruminant species in terms of their contribution to the national economy, providing 54 billion birr per annum. It contributes $45 \%$ of Ethiopia's agricultural Gross Domestic Product (IGAD Center for Pastoral Areas and Livestock Development, 2010).

The Foot and mouth disease (FMD) virus is a highly contagious and economically devastating disease of cloven-hooved domestic and wild animals. It has been suggested that the pastoralist livestock keeping areas in the East African region form ecosystems in which FMD is maintained (FAO/AU-IBAR/PACE FMD workshop, 2006). FMD is endemic in East Africa with six of the seven serotypes namely; O, A, C, SAT types 1, 2, and 3 reported to occur, thus complicating the epidemiology and control of the disease in the region (Vosloo et $a l .$, 2002). Out of the six FMD serotypes established in the sub-Saharan Africa, four (A, O, C and SAT 2) have been identified over the past ten years in Ethiopia; however, serotype C is not detected since 1993 (Gelagay Ayelet, 2008).

FMD is one of the major endemic trans-boundary livestock diseases of socioeconomic importance in Ethiopia and in other parts of the globe. The seroprevalence prevalence of FMD in different regions of Ethiopia as indicated by different studies accounted that, the prevalence in Borena zone of Oromia Regional State was 53.6\% (Habtamu Mekonnen et al., 2011; Gelagay Ayelet, et al., 2012). The other studies also indicated that the prevalence of FMD in Eastern zone of Tigray, Yeka (Addis Ababa) and Guji zone of Oromia Regional State was accounted $41.5 \%, 32.7 \%$ and $30 \%$ respectively. Moreover, other studies indicated that the prevalence in Bale zone was 21.9\% (Misgana Duguma et al., 2013), in Somali was 14.05\% (Abdulahi Mohamed et al., 2011) and in 
around Dessie zuria and Koombolcha area was 5.59\% (Abraha Gebregziabher and Ahmed Issa, 2013). Therefore, the aim of this sero-survelliance was to determine the prevalence of FMD in selected Kebelles/ Peasant associations which are located adjacent to the major livestock markets (Yabello, Dubuluk and Moyale) in Borena zone, Oromiya Regional State.

\section{Materials and Methods}

\section{Study area}

The study was conducted in Yabello, Dire and Moyale districts of Borena zone, Oromiya Regional State. The three districts were selected benchmarking the big livestock markets in the zone such as Harroo Beke, Dubuluk and Moyale. A total of nine peasant associations (PA's) based on expert suggestion and livestock population were selected during the study. Borana zone is mostly pastoral and covers a vast lowland area in southern Ethiopia. It has an area of about $95,000 \mathrm{Km}^{2}$ and is located at $567 \mathrm{Km}$ from Addis Ababa between $03^{\circ} 37^{\prime} 23.8^{\prime \prime}$ to $05^{\circ} 02^{\prime} 52.4^{\prime \prime}$ North (latitude) and $37^{\circ} 56^{\prime} 49.4^{\prime \prime}$ to $39^{\circ} 01^{\prime} 101^{\prime \prime}$ East (longitude), in the Southern part of Ethiopia. The altitude ranges from 970 meter above sea level in the south, bordering Kenya to 1693 meter above sea level in the North east. The area receives mean annual rainfall ranges between $330 \mathrm{~mm}^{3}$ to $600 \mathrm{~mm}^{3}$ having mean minimum and maximum annual temperatures of $19^{\circ} \mathrm{C}$ and $26^{\circ} \mathrm{C}$, respectively (Beatric et al., 2009). It is dominated by savannah vegetation containing mixture of perennial and woody bush land. The major water sources are ponds and deep well (Helland, 1997).

\section{Study population}

The study animals were cattle of Borena breeds of different age groups and sex selected from the three districts of Borena zone. A total of 363 cattle were included during the study period as explained in the study design below.

\section{Study design}

A cross-sectional study was carried out between April and November 2015 to investigate the sero-prevalence of FMD in cattle in Borena zone, Ethiopia. Peasant associations were selected randomly from each district. The sample size was based on simple random sampling techniques with the following predetermined parameters, that is a prevalence of $21 \%$ (Tesfaye Rufel et al., 2008), 
a confidence level of $95 \%$ and a specified error of $5 \%$. Though a total of 255 cattle were needed, to increase the precision of the finding the sample size was increased to 363 and cattle were randomly selected to be included in the study.

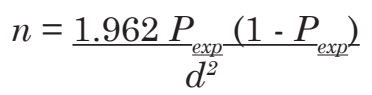

Where $n=$ required sample size; $P_{\text {exp }}=$ expected prevalence (\%); and $d=$ desired absolute precision (\%).

During sample collection, the ages of each of the sampled animals were determined by consulting the owners of the cattle. Accordingly, the sampled animals were categorized as calves ( $<1$ years), young (1-3 years) and adults ( $>3$ years).

\section{Questionnaire survey}

A semi-structured questionnaires containing inquires related to FMD were prepared and used during the investigation. The cattle owners expressed their views and shared their practical knowledge's about the prevailing situations regarding FMD using their own language (Oromifa) to the investigation group which included awareness about clinical signs of FMD, age affected, sex affected, seasons of FMD outbreak, livestock movement, wind direction, status of vaccination and water sources for the livestock.

\section{Sample collection}

Blood samples were drawn by puncture of the jugular vein using plain sterile vacutainer tubes. The vacutainer tubes containing the blood were maintained inclined overnight at room temperature for serum separation and each serum sample was transferred into sterile cryovial, labeled and stored at $-20^{\circ} \mathrm{C}$ until analysis. Finally, the sera were transported in an ice box with ice packs to the National Animal Heath Diagnostic and Investigation Center (NAHDIC), Sebeta, Ethiopia.

\section{Serological test}

A total of 363 sera were tested, using the CHEKIT-FMD 3ABC bovine ELISA kit (IDEXX Switzerland AG, Switzerland). The ELISA kit has 95\% sensitivity and $97 \%$ specificity, for identifying previously infected animals. All the reagents, buffers, microplates and reactive and non-reactive control sera were supplied by the manufacturer and the test was performed as per their guide- 
line. Briefly, both the test and reference sera were diluted 1:100 in CHEKITFMD-3ABC sample diluent and dispense 100 $\mathrm{\mu l}$ of prediluted samples and controls in the appropriate wells of the microtiter plate and cover the micro titer plate and incubated for 60 minutes $\left( \pm 10\right.$ minutes) at $37 \pm 2^{\circ} \mathrm{C}$ in humidified incubator. Any antibody specific for $3 \mathrm{ABC}$ protein binds to the antigen in the wells. Each well was washed with approximately $300 \mu$ of CHEKIT wash solution three times. The liquid content of all wells after each wash was aspirated. Dispensed $100 \mathrm{\mu l}$ a proxidase labeled CHEKIT-FMD-bov-ov Anti-Ruminant-IgGconjugate and was added which binds to antibody of sample complexes with antigen. Each well was washed with approximately $300 \mu \mathrm{l}$ of CHEKIT wash solution three times. The liquid contents of all wells after each wash were as-

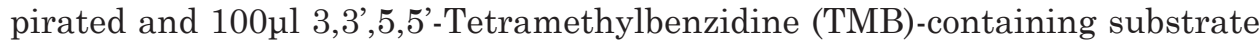
was added to the wells and incubated for 15 minutes at room temperature. Finally, the color reaction was stopped by adding CHEKIT stop solution TMB per well. The degree of color development (optical density measured at $450 \mathrm{~nm}$ ) is directly proportional to the amount of antibody in the sample serum specific to the antigen.

The results of the test sera were expressed as an index, derived by dividing the absorbance value of the serum tested with reference of the Optical density (OD) of reference negative and positive controls. The formula used to calculate percent sero-reactivity is

$$
\text { Value } \%=\frac{O D \text { sample }- \text { OD neg }}{O D \text { pos }-O D \text { neg }} \times 100
$$

Where OD = optical density:

Interpretation of the results: a percentage value of $<20 \%$ is negative; $\geq 20 \%$ to $<30 \%$ is suspect and $\geq 30 \%$ is positive.

\section{Statistical analysis}

The $3 \mathrm{ABC}$ test results for each animal and its origin (village, district) were recorded in a Microsoft Excel spreadsheet. Descriptive statistical analysis and logistic regressions were carried out using SPSS version 20 (Armonk, NY: IBM corp., USA). The association of FMD sero-prevalence with different risk factors such as age, sex and district was determined using logistic regression. The maps were generated using ArcGISv9.0 (ESRI, Redlands, California, USA). In 
all the analysis confidence level was set at $95 \%$ and $P$ value $\leq 0.05$ was set for significance.

\section{Results}

\section{Serological findings}

\section{FMD sero-prevalence by districts}

Out of 363 sera samples, $42.7 \%$ [95\%CI $=37.7-47.84$ ] were tested positive for FMD antibody using the 3ABC-ELISA test. The highest prevalence was found in Dire district which accounted 52.8\% [95\%CI, 44.0-61.4] (Table 1). The study indicated that there was statistical significance difference $\left(\mathrm{X}^{2}=10.43, \mathrm{P}=\right.$ 0.005) in the prevalence of FMD in between districts.

Table 1: Seroprevalence of FMD in the selected districts

\begin{tabular}{lccc}
\hline Districts & $\begin{array}{c}\text { Number of sera } \\
\text { tested }\end{array}$ & $\begin{array}{c}\text { Number of tested positive } \\
\text { (\%) }\end{array}$ & Prevalence (95\% CI) \\
\hline Dire & 125 & 66 & $47.2(44.0-61.4)$ \\
Moyale & 68 & 20 & $29.4(19.5-41.02)$ \\
Yabello & 170 & 69 & $40.6(33.4-48.1)$ \\
Total & 363 & 155 & $42.7(37.7-47.84)$ \\
\hline $\mathrm{x}^{2}=10.43, \mathrm{P}=0.005$ & & &
\end{tabular}

\section{FMD seroprevalence by peasant association}

The prevalence of FMD was higher in Soda peasant association of Dire district and Surupa peasant association of Yabello district which accounted for $65.5 \%$ (95\% CI, 49.4-78.5) and 65.0\% (95\% CI= 40.4-78.5), respectively (Table 2). The lowest seroprevalence was found in Bokela and Legsure peasant associations of Moyalle district which was estimated to be $25.6 \%(95 \% \mathrm{CI}=13.8-41)$ and $34.5 \%$ (95\% CI=19.0-52.9), respectively. There was statistically significant difference in FMD prevalence between peasant associations $\left(\mathrm{X}^{2}=31.1, \mathrm{P}=0.000\right)$ 
Table 2: Sero-prevalence of FMD in peasant associations of different districts found in Borena zone of Oromia

\begin{tabular}{lccc}
\hline Districts & $\begin{array}{c}\text { Number of } \\
\text { sera tested }\end{array}$ & $\begin{array}{c}\text { Number of testing Positive } \\
\text { (\%) }\end{array}$ & Prevalence (95\% CI) \\
\hline Dire & 125 & 66 & $47.2(44.0-61.4)$ \\
Dida bedena & 40 & 16 & $40(25.8-55.3)$ \\
Soda & 40 & 26 & $65.5(49.4-78.5)$ \\
Dokole & 45 & 24 & $53.3(38.8-67.5)$ \\
Moyale & 68 & 20 & $29.4(19.5-41.02)$ \\
Bokola & 39 & 10 & $25.6(13.8-41)$ \\
Legesure & 29 & 10 & $34.5(19.0-52.9)$ \\
Yabello & 170 & 69 & $40.6(33.4-48.1)$ \\
Chiro & 45 & 12 & $26.7(15.3-40.9)$ \\
Harbore & 40 & 17 & $42.5(27.9-58.1)$ \\
Surupha & 40 & 26 & $65(40.4-78.5)$ \\
Elewoya & 45 & 14 & $31.1(43.1-71.5)$ \\
Total & 363 & 155 & $42.7(37.7-47.84)$ \\
\hline X2=31.1, P=0.000 & & &
\end{tabular}

\section{Sex and age difference in FMD seroprevelance}

The current study revealed that the prevalence of FMD was higher in adult and female cattle which accounted for $52.0 \%(95 \% \mathrm{CI}=44.6-59.2)$ and $45.0 \%$ $(95 \% \mathrm{CI}=38.9-51.4)$, respectively. There was significance difference $\left(\mathrm{X}^{2}=17.4\right.$, $\mathrm{P}=0.001)$ in the prevalence of FMD between age groups. However, the prevalence of FMD was no significantly different $\left(X^{2}=1.63, P=0.202\right)$ between male and female cattle (Tables 3 and 4).

Table 3: Seroprevalence of FMD in different age groups

\begin{tabular}{lccc}
\hline Age & $\begin{array}{c}\text { Number of sera } \\
\text { tested }\end{array}$ & $\begin{array}{c}\text { Number of testing } \\
\text { Positive (\%) }\end{array}$ & Prevalence (95\%CI) \\
\hline Calves & 28 & 4 & $14.3 \%(4.8-31)$ \\
Young & 156 & 58 & $37.2 \%(29.9-45)$ \\
Adult & 179 & 93 & $52.0(44.6-59.2)$ \\
Total & 363 & 155 & $42.7(37.7-47.84)$ \\
\hline
\end{tabular}


Asamenew Tesfaye et al.,

Table 4: Seroprevalence of FMD between the two sexes

\begin{tabular}{lccc}
\hline Sex & $\begin{array}{c}\text { Number of sera } \\
\text { tested }\end{array}$ & $\begin{array}{c}\text { Number of testing positive } \\
\text { (\%) }\end{array}$ & Prevalence(95\%CI) \\
\hline Male & 121 & 46 & $38.0(29.7-46.9)$ \\
Female & 242 & 109 & $45.0(38.9-51.4)$ \\
Total & 363 & 155 & $42.7(37.7-47.84)$ \\
\hline $\mathrm{x}^{2}=1.63, \mathrm{P}=0.202$
\end{tabular}

\section{Risk factors}

Table 5: Logistic regression values to determine associated risk factors (district, age and sex) for FMD in Borena zone

\begin{tabular}{lccccc}
\hline Risk factor & In OR & DF & OR & 95\% CI & P-value \\
\hline District & 0.493 & 2 & 1.637 & $1.028-2.601$ & 0.006 \\
age & 0.603 & 2 & 1.827 & $1.180-2.830$ & 0.000 \\
sex & 0.290 & 1 & 1.336 & $0.855-2.087$ & 0.203 \\
\hline
\end{tabular}

The present study revealed that districts and age were identified as risk factors for FMD at $\mathrm{p}=0.0006$ and $\mathrm{P}=0.000$, respectively. Although there was no statistically significance difference in the prevalence of FMD in between sex $(p=0.202)$, the prevalence of the disease were higher in Female animals (Table 5).

\section{Questionnaire survey}

This survey revealed that pastoralists are well aware of the clinical signs of FMD and it was known by local name Oyale. FMD outbreak was commonly seen during June to August (Short rainy season) and December to February (Long dry season), locally called Adolessa and Bona, respectively. They are using communal grazing land, pond and rivers which are used as watering point. Livestock movement is common during drought season to look for water and grass. They trek $3-100 \mathrm{~km}$ and stays there for 2-9 months (Figure 1 and 2) depending on the longevity of the dry season. The pastoralists reported that $66.7 \%$ of young cattle (1-3years) were affected as compared to adults (>3years) and calves (<1year). 


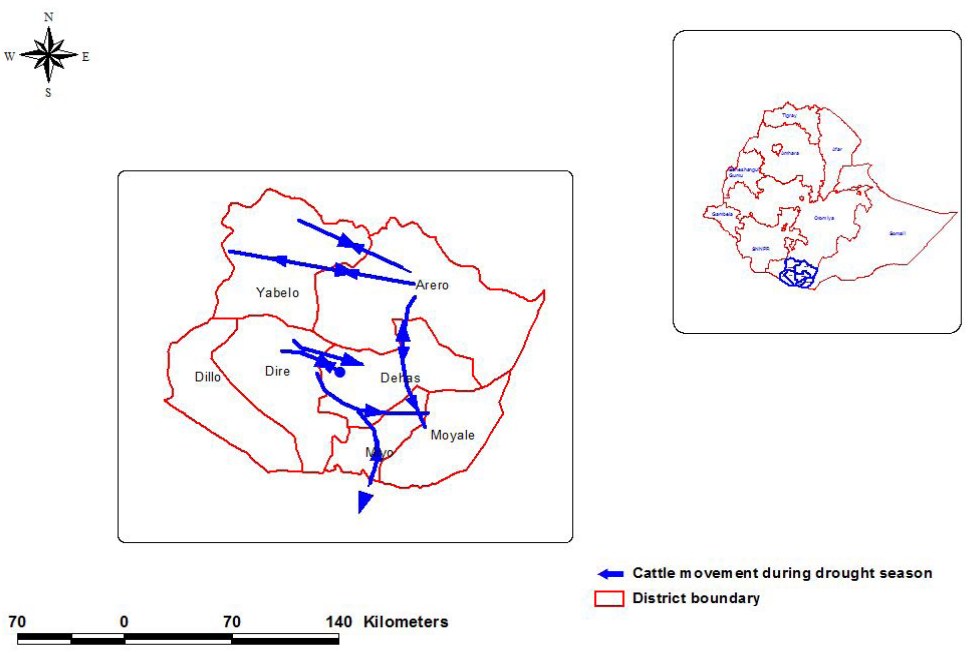

Figure 1: Livestock movement during drought season

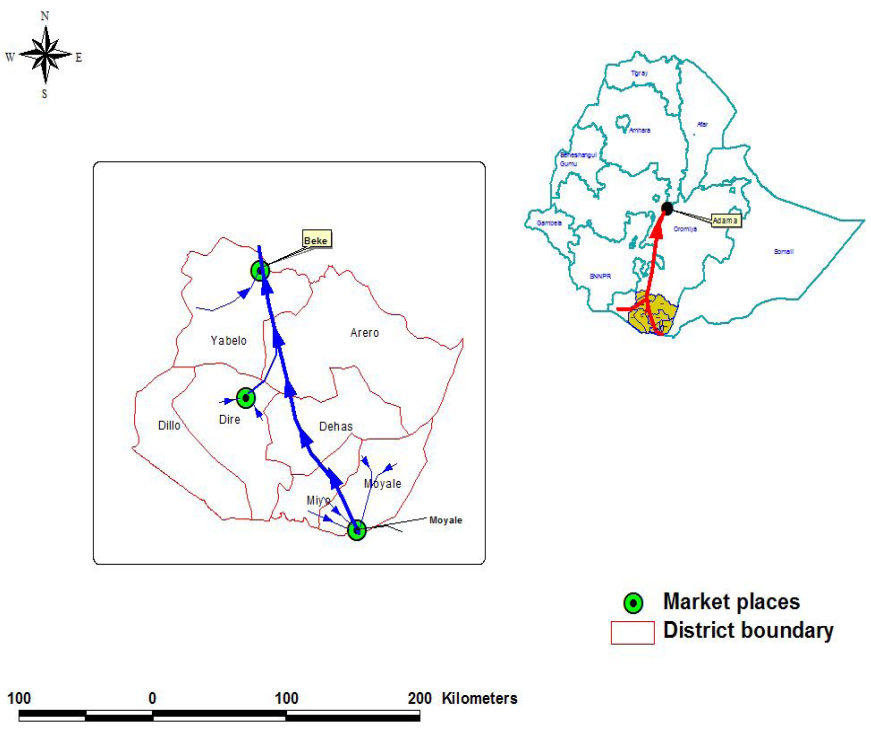

Figure 2: Livestock market routs in Borena Zone 


\section{Discussion}

FMD is enzootic in most parts of Africa including Ethiopia, and only a few countries on the continent have managed to control the disease to allow access to profitable export markets for live animals and animal products (Mesfin Sahle, 2004; Vosloo et al., 2002). The disease was reported to cause obstacles for about 6\% of export animal products in Ethiopia (Bedru, 2006) and it is an economically important disease in the country with frequency of incidence ranges 1.3 to 1.5 times since 1990 (MOA, 2000).

An overall FMD prevalence of 42.7 (155/363) was observed in this study. This finding was higher than previously reported by Mesfin Sahel (2004), Tesfaye Rufeal et al. (2008) and Gelagay Ayelet et al. (2012) who reported 26.25\%, 21\% and $10.5 \%$ respectively. The higher difference between the current study and the previous once might be due to a prevailing disease outbreak in the study areas and sensitivity and specificity of the test used According to the questionnaire survey conducted in this study, there was a severe outbreak of FMD in the area six months before this study was conducted. The current finding indicated that there was statistically significant difference $(P=0.005)$ in the prevalence of FMD among districts which was higher than the findings of Tesfaye Rufael et al. (2008) in Borana pastoral and Misgana Duguma et al. (2013) indicate that the prevalence of the disease was significantly different between districts which was in agreement with this study.

The study revealed a significant variation $\left(\mathrm{X}^{2}=17.4, \mathrm{P}=0.001\right)$ on sero-positivity of FMD in different age groups in which significantly higher seroprevalence of FMD in young and adult animals than in claves. The current study is in agreement with the previous reports of Tesfaye Rufael et al. (2008) in Borena pastoral area, Bereket Molla et al. (2010) in south Omo zone, Megersa Bekele et al. (2009) in Gamo gofa and Sidama zones, Abdulahi Mohamed et al. (2011) in Awbere and Babille districts of Jijiga zone, Somalia Regional State and Fufa Abuna et al. (2013) in Dire Dawa and its surroundings in Eastern Ethiopia. On the other hand, Esayas Gelaye et al. (2009) who conducted their research in Bench Maji zone of southern Ethiopia documented absence of significant association between sero-positivity of FMD and age of cattle. The relatively low seroprevalence in age group less than one year (calves) in the current study might indicate prevailing passive maternal immunity and low frequency of exposure go FMD virus as the Borana pastoralists keep this age group in warra 
herd, around permanent encampments. The study also indicated no significant difference $\left(\mathrm{X}^{2}=1.63, \mathrm{P}=0.202\right)$ between male and female cattle which is in agreement with the findings of Fufa Abuna et al. (2013), Abdulahi Mohamed et al. (2011), Tesfaye Rufael et al. (2008) and Habtamu Mokonnen et al. (2011) in different parts of Ethiopia.

\section{Conclusion}

In conclusion, FMD is an important transboundery animal disease that affects the livelihood of farmers and economy of the country. In pastoral areas like Borena where livestock movement is common during dry season, the disease is devastating and spreading from one area to the other within the Borena Zone. Therefore, an extensive regular serological survey, virus isolation, and characterizations of FMD virus need to be conducted for a possible development of poly-valent vaccines that contains commonly circulating serotypes of FMD virus in Ethiopia.

\section{Acknowledgements}

We are grateful to NAHDIC in supporting this serosurveillance study and Dr. Getachew Gari for his constructive comments during this manuscript preparation. We also appreciate Borena zona regional veterinary laboratory staffs for their kind support.

\section{References}

Abdulahi, M., Esaya, T. and Hailu D., 2013. Seroprevalence of bovine foot and mouth disease (FMD) in Awbere and Babille districts of Jijiga zone, Somalia Regional State, Eastern Ethiopia. Afr. J. Microbiol. Res., 5(21), 3559-3563.

Abraha, G. and Ahmmed I., 2013. Sero-prevalence of foot and mouth disease in cattle in Dessie Zuria and Kombolcha Area, South Wollo, Ethiopia. Vet. Res., 6(1), 1-9.

Ayelet, G., Gelaye, E., Negussie, H. and Asmare, K., 2012. Study on the epidemiology of foot and mouth disease in Ethiopia. Rev. sci. tech. Off. int. Epiz., 31 (3), 789-798.

Beatrice, R., Excellent, H., Cynthia, B. and Anne, H., 2009: Climate related vulnerability and adaptive capacity in Ethiopia's Borana and Somali communities. Final assessment report. Save the children, UK. Pp. 24

Ethiop. Vet. J., 2016, 20 (1), 55-66 
Bedru, H., 2006. Sero-prevalence study of foot and mouth disease in export Bulls of Borana and Jimma origin, Ethiopian DVM Thesis, Faculty of Veterinary Medicine, Addis Ababa University, Debre Zeit: 1-21.

Esayas, G., Gelagay, A., Tsegalem, A. and Kassahun, A., 2009. Seroprevalence of foot and mouth disease in Bench Maji zone, southwestern Ethiopia. J. Vet. Med. Anim. Heal., (1), 5-10.

FAO/AU-IBAR/PACE, 2006. Joint meeting on foot-and-mouth disease; regional co-ordination and emergency control in the African Great lakes countries of Rwanda, Burundi, Democratic Republic of Congo, Tanzania and Uganda. Nairobi, Kenya 3-4th August 2006.

Habtamu, M., Desta, B., Tesfaye, R., Ashenafi, F. and Fufa, A., 2011. Study on the prevalence of foot and mouth disease in Borana and Guji Zones, Southern Ethiopia. Vet. World., 4(7), 293-296.

IGAD Center for Pastoral Areas and Livestock Development (ICPALD), 2010. The Contribution of Livestock to the Ethiopian Economy. Policy Brief series. Policy Brief No: ICPALD 5/CLE/8/2013

Megersa, B., Beyene, B., Abunna, F., Regassa, A., Amenu, K. and Rufael, T., 2009. Risk factors for foot and mouth disease sero-prevalence in indigenous cattle in Southern Ethiopia: The effect of production system. Trop. Anim. Health Prod., 41, 891-898.

Misgana, D., Yasmin J., Ahmed, I. and Addisalem, H., 2013. Seroprevalence of foot and mouth disease of cattle in Bale Zone, Oromiya Regional State, Ethiopia. Global Vet., 11 (1), 59-64.

MOA, 2000. Ministry of Agriculture: Annual Report on disease of livestock of Ethiopia. Veterinary Service Department.

Molla, B., Ayelet, G., Asfaw, Y., Jibril, Y., Ganga, G. and Gelaye, E., 2010. Epidemiological study on foot-and-mouth disease in cattle: Seroprevalence and risk factor assessment in South Omo Zone, South-western Ethiopia. Trans. Emerg. Infect. Dis., 57, 340-347.

Rufael, T., Catley, A., Bogale, A., Sahle, M. and Shiferaw, Y., 2008. Foot and mouth disease in the Borana pastoral system, southern Ethiopia and implications for livelihoods and international trade. Trop. Anim. Health Prod., 40, 29-38.

Sahle, M., 2004. An epidemiological study on the genetic relationships of foot and mouth disease viruses in east Africa. $\mathrm{PhD}$ thesis submitted to the Department of Veterinary Tropical Diseases, Faculty of Veterinary Science, University of Pretoria, South Africa

Vosloo, W., Bastos, A.D.S., Sangare, O., Hargreaves, S.K. and Thomson, G.R., 2002. Review of the status and control of foot and mouth disease in sub-Saharan Africa. In Foot and mouth disease: facing the new dilemmas. Rev. sci. tech. Off. int. Epiz., 21(3), 437-447. 